\title{
GAMBARAN PENGETAHUAN MILLENIUM DEVELOPMENT GOALS (MDG'S) PADA MAHASISWA MAHASISWA FAKULTAS KEDOKTERAN PROGRAM STUDI KEDOKTERAN UMUM SEMESTER ENAM (VI) UNIVERSITAS SAM RATULANGI MANADO
}

\author{
${ }^{1}$ Rahmat Thariq \\ ${ }^{2}$ Ronald I. Ottay \\ ${ }^{2}$ Henry M. F. Palandeng
}

\author{
Kandidat Skripsi Fakultas Kedokteran Universitas Sam Ratulangi Manado \\ Bagian Ilmu Kedokteran Preventif Iniversitas Sam Ratulagi Manado \\ Email: Arywaisamole@gmail.com
}

\begin{abstract}
MDG's is a declaration that the commitment of world leaders to address the issues of peace, security, development, human rights and fundamental freedoms in one package. Target achievement of the MDG's, the dominant of which are issues that are within the scope of health, it became evident that health is the main component that is considered by the world community. Methods: This study aims to gain insight knowledge of medical students about the MDG's. The research was conducted at the Faculty of Medicine, General Medicine course Sam Ratulangi University Manado in October 2012 until April 2013. A total of 90 respondents were collected and then conducted data collection using questionnaires. Likert scale is used as a means of interpretation of the respondents' knowledge. Results: of 90 respondents, the overall level of knowledge about the Millennium Development Goals (MDG's) well with the percentage of $70.75 \%$. Conclusion: the knowledge of students in the Faculty of Medicine, General Medicine course Sam Ratulangi University of Manado on the purpose and benefits of the Millennium Development Goals (MDG's) showed good knowledge.
\end{abstract}

\begin{abstract}
Abstrak: MDG's merupakan Deklarasi yang menghimpun komitmen para pemimpin dunia untuk menangani isu perdamaian, keamanan, pembangunan, hak asasi dan kebebasan fundamental dalam satu paket. Target pencapaian MDG's, dominan diantaranya merupakan permasalahan yang berada dalam ruang lingkup kesehatan, hal ini menjadi bukti bahwa kesehatan merupakan komponen utama yang sangat diperhatikan oleh masyarakat dunia. Metode: Penelitian ini bertujuan untuk mendapatkan gambaran pengetahuan Mahasiswa kedokteran tentang MDG's. Penelitian ini dilaksanakan di Fakultas Kedokteran program studi Kedokteran Umum Universitas Sam Ratulangi Manado pada bulan Oktober 2012 sampai April 2013. Sebanyak 90 responden dikumpulkan kemudian dilakukan pengambilan data menggunakan kuesioner. Skala likert digunakan sebagai alat interpretasi pengetahuan responden. Hasil: dari 90 responden, secara keseluruhan tingkat pengetahuan tentang Millenium Development Goals (MDG's) baik dengan presentase 70,75 \%. Simpulan: pengetahuan mahasiswa di Fakultas Kedokteran program studi Kedokteran Umum Universitas Sam Ratulangi Manado tentang tujuan dan manfaat Millenium Development Goals (MDG’s) menunjukan pengetahuan yang baik.
\end{abstract}

Tahun 2015 merupakan tahun dimana seluruh masyarakat dunia mendukung atas pencapaian suatu tujuan global. Sebanyak 189 negara anggota Perserikatan Bangsa-
Bangsa (PBB) yang sebagian besar diwakili oleh kepala negara sepakat untuk mengadopsi deklarasi milenium pada Konferensi Tingkat Tinggi (KTT) bulan 
September tahun 2000. Deklarasi ini menghimpun komitmen para pemimpin dunia yang tidak pernah ada sebelumnya untuk menangani isu perdamaian, keamanan, pembangunan, hak asasi dan kebebasan fundamental dalam satu paket. Dalam konteks inilah, negara-negara anggota PBB kemudian mengadopsi Millenium Development Goals (MDG's) atau tujuan pembangunan millenium. Setiap tujuan memiliki satu atau beberapa target beserta indikatornya. MDG's menempatkan pembangunan manusia sebagai fokus utama pembangunan, memiliki batas waktu dan kemajuan yang terukur. MDG's didasarkan pada konsensus dan kemitraan global, sambil menekankan tanggung jawab negara berkembang untuk melaksanakan pekerjaan rumah mereka, sedangkan negara maju berkewajiban mendukung upaya tersebut. ${ }^{1}$

Indonesia telah mencapai target MDG's diantaranya tingkat kemiskinan yaitu proporsi penduduk yang hidup dengan pendapatan per kapita kurang dari USD 1 per hari, telah menurun dari 20,6 persen pada tahun 1990 menjadi 5,9 persen pada tahun 2008. Target untuk kesetaraan gender dalam semua jenis pendidikan perempuan terhadap laki-laki di sekolah dasar,sekolah menengah pertama dan sederajat berturutturut sebesar 99,73 persen dan 101,99 persen pada tahun 2009 dan rasio melek huruf perempuan terhadap laki-laki pada kelompok usia 15-24 tahun telah mencapai 99,85 persen. Penemuan kasus tuberkulosis terjadi peningkatan dari 20,0 persen pada tahu 2000 menjadi 73,1 persen pada tahun 2009, dari target 70,0 persen dan penurunan prevalensi tuberkulosis dari 443 kasus pada 1990 menjadi 224 kasus per 100.000 penduduk pada tahun $2009 .^{2}$

Indonesia juga memiliki target yang telah menunjukan kemajuan signifikan diantaranya prevalensi balita kekurangan gizi telah berkurang hampir setengahnya dari 31 persen pada 1989 menjadi 18,4 persen pada 2007, target 2015 sebesar 15,5 persen. Angka pendidikan dasar mendekati 100 persen dan tingkat melek huruf penduduk melebihi 99,47 persen pada tahun 2009. angka kematian balita telah menurun dari 97 per 1000 kelahiran pada tahun 1991 menjadi 44 per 1000kelahiran pada tahun 2007. Beberapa target MDG's yang menunjukan kecenderungan pencapaian yang baik namun masih memerlukan kerja keras untuk pencapaian target pada tahun 2015 diantaranya angka kematian ibu menurun dari 390 pada tahun 1991 menjadi 228 per 100.000 kelahiran hidup pada tahun 2007. Jumlah penderita HIV/AIDS meningkat, khususnya diantara kelompok resiko tinggi pengguna narkoba suntik dan pekerja seks. ${ }^{3}$

Jika kita perhatikan target pencapaian MDG's, dominan diantaranya merupakan MDG's yang berada dalam ruang lingkup kesehatan. Suatu hal yang menarik, hal ini menjadi bukti bahwa kesehatan merupakan komponen utama yang sangat diperhatikan oleh masyarakat dunia. Dan bisa kita simpulkan bahwa segala yang terkait dengan peningkatan faktor kesehatan masyarakat merupakan komponen penting dalam percepatan terwujudnya MDGs. Segala hal yang terkait misalnya fasilitas pelayanan kesehatan seperti rumah sakit dan puskesmas, kemudian pelayan kesehatan itu sendiri seperti dokter, perawat, bidan, sampai dengan komponen kesehatan lainnya seperti mahasiswa bidang kesehatan, baik itu mahasiswa jurusan kesehatan masyarakat, keperawatan, farmasi, dan juga pendidikan dokter merupakan elemen masyarakat yang perlu dimaksimalkan perannya. Mahasiswa kedokteran diyakini memiliki peran yang sangat penting dalam menyambung tali kesehatan masyarakat Indonesia di masa yang akan datang. Dan potensi peran yang besar ini bisa dijadikan semacam cambuk untuk bisa berperan sejak masih kuliah. MDGs bisa menjadi trigger sehingga seorang mahasiswa kedokteran bisa memberikan kontribusi positif bagi percepatan pencapaian target MDGs. ${ }^{4}$

Keberhasilan pencapaian MDG's juga merupakan keberhasilan masyarakat sehat dengan pengertian "sehat" menurut World Health Organization (WHO) adalah suatu keadaan yang sempurna baik secara fisik,mental dan sosial serta tidak hanya bebas dari penyakit atau kelemahan. ${ }^{5}$ 
Penelitian ini bertujuan untuk mendapatkan gambaran pengetahuan Millenium Development Goals (MDG's) pada mahasiswa mahasiswa Fakultas Kedokteran program studi Kedokteran Umum semester enam (VI) Universitas Sam Ratulangi Manado.

\section{METODE}

Penelitian ini merupakan suatu penilitian deskriptif kuantitaif dengan menggunakan metode survei. Penelitian ini dilaksanakan di Fakultas Kedokteran program studi Kedokteran Umum Universitas Sam Ratulangi Manado pada bulan Oktober 2012 sampai April 2013. Populasi yang diteliti adalah kelompok mahasiswa yang ada di Universitas Sam Ratulangi, yaitu Fakultas Kedokteran program studi Kedokteran Umum. Kriteria mahasiswa yang akan diteliti, yaitu pada semester enam (VI) dengan jumlah populasi 278 orang. Teknik pengambilan sampel yang digunakan dalam penelitian ini, yaitu dengan menggunakan rumus Snedecor Cochran ${ }^{11}$ sehingga didapatkan 90 sampel.Variabel Yang Diteliti meliputi Pengetahuan Responden tentang Tujuan MDG's dan Manfaat MDG's.

Pengambilan data dilakukan menggunakan kuesioner. Pengumpulan data dalam penelitian ini dilakukan dengan memberikan kuesioner kepada seluruh responden yang berjumlah 278 orang. Setelah itu akan dipilih 90 responden sebagai sampel dengan meggunakan Systematic Random Sampling yaitu penomoran pada kuesioner kemudian secara sistematik peneliti mengambil angka genap pada kusioner. Data diolah kemudian disajikan dalam bentuk tabel dan teks, kemudian dianalisa berdasarkan presentase. Pengukuran pengetahuan didasarkan pada jawaban responden dari semua pertanyaan yang diberikan dan diukur dengan menggunakan skala likert yaitu skala yang menginginkan keragaman jawaban dengan melihat kondisi populasi yang diteliti. Untuk jawaban positif seperti ya, setuju, benar, pernah dam semacamnya diberi skor 2 sedangkan untuk jawaban negatif seperti tidak setuju, salah, tidak, tidak pernah dan semacamnya diberi skor 0 . Untuk jawaban yang belum diketahui seperti kadangkadang, ragu-ragu dan semacamnya diberikan skor 1. Interpretasi penilaian pengetahuan berdasarkan skala likert $:^{12,13}$

1. Tingkat pengetahuan kurang apabila jawaban responden benar 0 - 33\% (skor 0-10) dari total skor

2. Tingkat pengetahuan cukup apabila jawaban responden benar 33 - 66\% (skor 11-21) dari total skor

3. Tingkat pengetahuan baik apabila jawaban responden benar 66 - 100\% (skor 22-32) dari total skor

\section{HASIL}

\section{Karakteristik Responden}

\begin{tabular}{|c|c|c|}
\hline \multicolumn{3}{|l|}{ Karakteristik reponden } \\
\hline Umur (Tahun) & Frekuensi & $\%$ \\
\hline 17 & 10 & 11,1 \\
\hline 18 & 25 & 27,8 \\
\hline 19 & 36 & 40 \\
\hline 20 & 17 & 18,9 \\
\hline 21 & 1 & 1,1 \\
\hline 22 & 1 & 1,1 \\
\hline \multicolumn{2}{|l|}{ Jumlah } & \multirow[t]{2}{*}{90} \\
\hline \multicolumn{2}{|l|}{100} & \\
\hline Jenis Kelamin & Frekuensi & $\%$ \\
\hline Laki - laki & 42 & 46,7 \\
\hline Perempuan & 48 & 53,3 \\
\hline \multicolumn{2}{|l|}{ Jumlah } & \multirow[t]{2}{*}{90} \\
\hline \multicolumn{2}{|l|}{100} & \\
\hline Pernah dengar & Frekuensi & $\%$ \\
\hline $\mathrm{Ya}$ & 77 & 85,5 \\
\hline Tidak & 12 & 13,3 \\
\hline Ragu-ragu & 1 & 1,1 \\
\hline Jumlah & & 90 \\
\hline \multicolumn{3}{|l|}{100} \\
\hline Sumber informasi & Frekuensi & $\%$ \\
\hline Teman & & 18,9 \\
\hline $\begin{array}{l}\text { Buku,internet,koran } \\
\text { majalah, radio }\end{array}$ & 32 & $\begin{array}{l}10,9 \\
35,6\end{array}$ \\
\hline ,televisi & & 288 \\
\hline Mata kuliah & $\begin{array}{l}\angle 6 \\
15\end{array}$ & $\begin{array}{l}28,8 \\
167\end{array}$ \\
\hline Lain-lain & 15 & 16,7 \\
\hline Jumlah & & 90 \\
\hline 100 & & \\
\hline
\end{tabular}




\section{Pengetahuan Responden}

\begin{tabular}{|c|c|c|}
\hline \multicolumn{3}{|l|}{ Pengetahuan Responden } \\
\hline Kepanjangan MDG’s & Frekuensi & $\%$ \\
\hline Ya & 71 & 78,9 \\
\hline Tidak & 12 & 13,3 \\
\hline Ragu-ragu & 7 & 7,8 \\
\hline Jumlah & 90 & 100 \\
\hline Program PBB & Frekuensi & $\%$ \\
\hline Ya & 67 & 74,4 \\
\hline Tidak & 16 & 17,8 \\
\hline Ragu-ragu & 7 & 7,8 \\
\hline Jumlah & 90 & 100 \\
\hline Jumlah tujuan MDG’s & Frekuensi & $\%$ \\
\hline Yа & 71 & 78,9 \\
\hline Tidak & 12 & 13,3 \\
\hline Ragu-ragu & 7 & 7,8 \\
\hline Jumlah & 90 & 100 \\
\hline Batas waktu MDG's & Frekuensi & $\%$ \\
\hline Ya & 80 & 80,9 \\
\hline Tidak & 10 & 11,1 \\
\hline Ragu-ragu & - & - \\
\hline Jumlah & 90 & 100 \\
\hline Tanggung jawab WHO & Frekuensi & $\%$ \\
\hline Ya & 65 & 72,2 \\
\hline Tidak & 19 & 21,1 \\
\hline Ragu-ragu & 6 & 6,7 \\
\hline Jumlah & 90 & 100 \\
\hline Membrantas HIV & Frekuensi & $\%$ \\
\hline Yа & 78 & 86,7 \\
\hline Tidak & 12 & 13,3 \\
\hline Ragu-ragu & - & - \\
\hline Jumlah & 90 & 100 \\
\hline $\begin{array}{l}\text { Peneggulangan miskin dan } \\
\text { lapar }\end{array}$ & Frekuensi & $\%$ \\
\hline Ya & 60 & 66,7 \\
\hline Tidak & 17 & 18,9 \\
\hline Ragu-ragu & 13 & 14,4 \\
\hline Jumlah & 90 & 100 \\
\hline Kelestarian lingkungan & Frekuensi & $\%$ \\
\hline Ya & 68 & 75,6 \\
\hline Tidak & 14 & 15,6 \\
\hline Ragu-ragu & 8 & 8,8 \\
\hline Jumlah & 90 & 100 \\
\hline Kesetaraan gender & Frekuensi & $\%$ \\
\hline Ya & 53 & 58,9 \\
\hline Tidak & 32 & 35,5 \\
\hline Ragu-ragu & 5 & 5,6 \\
\hline Jumlah & 90 & 100 \\
\hline Pendidikan dasar & Frekuensi & $\%$ \\
\hline Yа & 68 & 75,5 \\
\hline Tidak & 16 & 17,8 \\
\hline Ragu-ragu & 6 & 6,7 \\
\hline Jumlah & 90 & 100 \\
\hline $\begin{array}{l}\text { Penurunan Kematian } \\
\text { Anak }\end{array}$ & Frekuensi & $\%$ \\
\hline Ya & 74 & 82,2 \\
\hline Tidak & 13 & 14,5 \\
\hline Ragu-ragu & 3 & 3,3 \\
\hline Jumlah & 90 & 100 \\
\hline
\end{tabular}

\begin{tabular}{ccc}
\hline Peningkatan kesehatan ibu & Frekuensi & $\mathbf{\%}$ \\
Ya & 68 & 75,6 \\
Tidak & 18 & 20 \\
Ragu-ragu & 4 & 4,4 \\
Jumlah & 90 & 100 \\
Kemitraan global & Frekuensi & $\%$ \\
Ya & 55 & 61,1 \\
Tidak & 21 & 23,3 \\
Ragu-ragu & 14 & 15,6 \\
Jumlah & 90 & 100 \\
Sasaran MDG's & Frekuensi & $\%$ \\
Ya & 76 & 84,4 \\
Tidak & 13 & 14,5 \\
Ragu-ragu & 1 & 1,1 \\
Jumlah & 90 & 100 \\
Kemajuan pembangunan & Frekuensi & $\%$ \\
Ya & 75 & 83,3 \\
Tidak & 9 & 10 \\
Ragu-ragu & 6 & 6,7 \\
Jumlah & 90 & 100 \\
Kesejahteraan masyarakat & Frekuensi & $\%$ \\
Ya & 70 & 77,8 \\
Tidak & 12 & 13,3 \\
Ragu-ragu & 8 & 8,9 \\
Jumlah & 90 & 100 \\
\hline
\end{tabular}

\section{DISKUSI}

Berdasarkan hasil penelitian pengetahuan tentang delapan tujuan Millenium Development Goals (MDG's), pengetahuan responden kategori baik yaitu pengetahuan responden tentang mencapai pendidikan dasar untuk semua dengan presentase 75,5 $\%$, hal ini berhubungan dengan upaya Indonesia mencapai target MDG's tentang pendidikan dasar sudah menuju pada pencapaian target 2015, bahkan Indonesia menetapkan pendidikan dasar melebihi taeget MDG's. ${ }^{16}$ Pengetahuan responden tentang menurunkan angka kematian anak dengan presentase 82,9 \%, hasil ini sesuai dengan penelitian yang dilakukan oleh Alvian Dwi Juli Rismawati tentang pengetahuan mahasiswa kebidanan tentang angka kematian anak melalui inisiasi menyusui dini dengan presentase 61,2\%. ${ }^{6}$ Pengetahuan responden tentang meningkatan kesehatam ibu dengan presentase 75,6 \%, Pengetahuan responden tentang memerangi HIV/AIDS dan penyakit menular lainnya dengan presentase $\quad 86,7 \%$, hasil ini sesuai dengan penelitian yang dilakukan oleh Desilianty Sari tentang pengetahuan 
mahasiswa program studi pendidikan dokter tentang HIV/AIDS dengan presentase 94 $\%{ }^{18}$ Pengetahuan responden tentang memastikan kelestarian lingkungan hidup dengan presentase 75,6 \% hasil ini sesuai dengan penelitian yang dilakukan oleh Veronika Kumurur tentang pengetahuan mahasiswa pascasarjana ilmu lingkungan hidup terhadap lingkungan hidup kota Jakarta dengan presentase 50-68 \% . ${ }^{19}$

Pengetahuan responden kategori cukup yaitu pengetahuan responden tentang mendorong kesetaraan gender dan pemberdayaan perempuan dengan presentase $58,9 \%$, pengetahuan responden tentang membangun kemitraan global dengan presentase $61,1 \%$, pengetahuan responden tentang menanggulangi kemiskinan dan kelaparan dengan presentase 66,7 \%,

Pengetahuan responden tentang manfaat MDG's, responden memiliki pengetahuan yang baik yaitu pengetahuan tentang MDG's memberikan kemajuan pembangunan di setiap negara dengan presentase 83,3\% dan pengetahuan tentang MDG's memberikan kesejahteraan pada masyarakat dengan presentase $77,8 \%$.

Pengetahuan responden tentang kepanjangan MDG's memiliki pengetahuan yang baik dengan presentase 78,9 \%. Pengetahuan responden tentang MDG's adalah salah satu program dari Perserikatan Bangsa-Bangsa (PBB) memliki pengetahuan yang baik 74,4 \%. Pengetahuan responden tentang MDG's memeliki delapan tujan memiliki pengetahuan yang baik dengan presentase 78,9 \%. Pengetahuan responden tentang target pencapaian MDG's adalah pada tahun 2015 memiliki pengetahuan yang baik dengan presentase $73,3 \%$. Pengetahuan responden tentang WHO adalah salah satu badan PBB yang bertanggung jawab melaksanakan MDG's memeliki pengetahuan yang baik dengan presentase $73,2 \%$.

Sesuai dari pembahasan diatas mengenai pengetahuan mahasiswa tentang MDG's dapat dilihat dari dukungan Universitas Gadja mada (UGM) yang menghinpum Deklarasi Youth Millennium Drive di Auditorium Fakultas Kedokteran (FK)
UGM dengan perwakilan 18 perguruan tinggi. Deklarasi yang dibacakan oleh Arifah Nur Sadrina ini menyampaikan lima poin penting yang disepakati oleh mahasiswa sebagai bentuk komitmen untuk mendukung pencapaian percepatan Millennium Development Goal (MDG's) Indonesia tahun 2015. Isi deklarasi meliputi, pertama, komitmen menumbuhkan iklim wirausaha masyarakat kecil dan menengah dengan mengoptimalkan pemanfaatan potensi daerah. Kedua, membantu memasyarakatkan pola hidup sehat sedini mungkin. Ketiga, membantu menyeimbangkan peranan pria dan wanita dalam masyarakat dan pemerintahan. Keempat, membantu memaksimalkan fungsi puskesmas dan posyandu sebagai lini pertama dalam pelayanan kesehatan terutama dalam menurunkan angka kematian ibu dan anak. Dan kelima, membantu meningkatkan mutu pendidikan bagi generasi muda bangsa Indonesia. ${ }^{20}$

Berdasarkan presentase pengetahuan maka seluruh skor dari 90 sampel dijumlahkan kemudian dibagi 32 (total skor) dikali 100 \%. Maka secara keseluruhan tingkat pengetahuan responden tentang Millenium Development Goals (MDG's) baik dengan presentase $70,75 \%$ menjawab ya.

\section{SIMPULAN}

1. Berdasarkan peneletian Gambaran Pengetahuan tentang Millenium Development Goals (MDG's) pada mahasiswa kedokteran semester enam (VI) mengenai tujuan MDG's mendapatkan kategori hasil yang baik sesuai dengan metode penilaian skala Likert.

2. Berdasarkan peneletian Gambaran Pengetahuan tentang Millenium Development Goals (MDG's) pada mahasiswa kedokteran semester enam (VI) mengenai manfaat MDG's mendapatkan kategori hasil yang baik sesuai dengan metode penilaian skala Likert.

\section{DAFTAR PUSTAKA}

1. Adisasmito w. analisis kemiskinann,MDGs dan Kebijakan Kesehatan Nasional.2010 desember 19 [2012 oktober 22]. Available 
from : http://staff.blog.ui.ac.id/wikua/files/2009/02/kemiskinan-mdgskebijakankes-nas_edited.pdf

2. S Armida, Sardjunani N, Pencapaian Tujuan Pembangunan Millenium.BAPPENAS;2010 p.6

3. Strategi dan Inovasi pencapaian MDG's 2015 di Indonesia Available from : from : www.pustaka.ut.ac.id/dev25/pdfprosiding2/f isip201236.pdf

4. Peran mahasiswa dalam pencapaian MDG's. Pradipta Suarsyaf. Available from : http://www.bempduinjkt.org/2012/09/peranmahasiswa-kedokteran-dalam.html

5. Defenisi WHO. World Health Organization Available from : http:// www.scribd.com/ doc/94690543/Sehat-Menurut-WHO-Adalah

6. Alisjahbana SA, Tuwo DL, Ringkasan Peta Jalan Percepatan Pencapaian Tujuan Pembangunan Millenium.BAPPENAS;2010 p.6

7. Nugroho $T$, Setiawan A.Kesehatan Wanita,Gender dan Permasalahannya.edisi 1 :Yogyakarta : nuMed;2010.p.30

8. Adnani H.Ilmu Kesehatan Masyarakat.edisi 1:Yogyakarta: nuMed;2011.p.61

9. Defenisi Pengetahuan. Mohammad Adlany. Available from: www.alhassanain.com/.. articles/.../definisi_pengetahuan/001.html

10. Notoatmodjo S. Promosi Kesehatan Teori dan aplikasi, edisi revisi. Jakarta: PT Rineka Cipta;2012

11. Pratiknya WA.Dasar-dasar Metodolgi penelitian kedokteran dan kesehatan. edisi 1 :Jakarta : Rajawali Pers; 2011.p.67
12. Instrument dan Cara Pengumpulan Data (online). [2012 oktober 22] avaible from : http://www.scribd.com/doc/52238595/20/sk ala-guttman

13. Tipe Skala Pengukuran (online) [2012 oktober 22]. avaible from : http://maskresno.wordpress.com/2008/01/30 /teknik-penulisan-instrumen-pengumpulandata

14. Evaluation of MDG's. Priadi Asmanto. Available from : http://papers.ssrn.com/ sol3/ papers.cfm?abstract_id=1996301

15. Harmonisasi Kebijakan MDG's di Indonesia. Emmy Latifah. Available from: http://fh.unsoed.ac.id/sites/default/files/filek u/dokumen/JDHvol112011/VOL11S2011\% 20EMMY\%20LATIFAH.pdf

16. Faktor penghambat MDG's. IKMA. Available from :http://ikma10fkmua.Files .wordpress.com/2013/03/mdgs.doc

17. Available from digilib.stikeskusumahusada.ac.id/download. php

18. Gambaran Pengetahuan Sikap dan perilaku tentang HIV/AIDS. Desilianty Sari. Available from jurnal.untan.ac.id/index.php/jfk/article/down load/1759/1700

19. Available from: repo.unsrat.ac.id /.../pengetahuan,_sikap_dan_kepedulian_ma hasiswa_pascasarj.pdf

20. Dua puluh mahasiswa dukung percepatan MDG's. Riani Dwi Lestari. Available from: m.okezone.com/read/2011/10/25/373/51997 3/20-mahasiswa 